\title{
EPIDEMIOLOGICAL CHARACTERIZATION OF CLOSTRIDIUM DIFFICILE INFECTIONS IN A RURAL COMMUNITY SETTING
}

\author{
Tache Traian ${ }^{1}$, Chirică Răzvann ${ }^{1}$, Radu Marius- Daniel ${ }^{2}$, Rugină Sorin ${ }^{1}$ \\ ${ }^{1}$ Faculty of Medicine, Ovidius University of Constanta, Romania \\ ${ }^{2}$ Faculty of Natural and Agricultural Sciences, Ovidius University of Constanta, Romania \\ Corresponding author: Tache Traian \\ Campus, Aleea Universității, nr. 1, Corp B, Constanta 900470, Romania \\ E-mail: tache_traian@yahoo.com
}

\begin{abstract}
Clostridium difficile is a microorganism - a Gram-positive anaerobic bacterium that has developed and hyperspecialized the ability to form spores. Outside the host, Clostridium difficile germinates spores which are resistant to unfavorable environment and for an extremely long time period. Clostridium difficile infection frequently occurs on a background of major disturbances in the balance of the normal intestinal flora caused by use for therapeutic purposes of broad-spectrum antibiotics. Patients infected with Clostridium difficile in medical facilities are usually elderly people, immunosuppressed or subjected to an antibiotic medication regimen. Wide-scale community use of antibiotics and proton-pump inhibitors induces favorable conditions for the germination of Clostridium difficile spores in the gastrointestinal tract.

Clostridium difficile biocolonizes many domestic and wild animals. Clostridium difficile is a complex bacterium, capable of developing resistance forms that parasitize the gastrointestinal tract of humans, and also many animals. An important source of the Clostridium difficile infection is represented primarily by antibiotic medication administered in communities without medical recommendation, as well as food.
\end{abstract}

Keywords: Clostridium difficile, biocolonization, resistance forms.

\section{Rezumat}

Clostridium difficile este un microorganism, bacterie Gram-pozitivă anaerobă ce are dezvoltată și hiperspecializată capacitatea de a forma spori. Clostridium difficile în afara gazdei formează spori rezistenți la mediul nefavorabil și pe o durată extrem de mare de timp. Infecția cu Clostridium difficile are loc frecvent pe fondul unor perturbări majore în echilibrul florei intestinale normale, produsă de utilizarea în scop terapeutic a antibioticelor cu spectru larg de acțiune. Pacienții infestați cu Clostridium difficile în unitățile medicale sunt, de obicei, persoane vârstnice, imunosupresate sau supuse unei scheme de medicație cu antibiotic. 


\section{INTERNAL}

\section{Original papers}

Utilizarea comunitară, pe scară largă a antibioticelor și inhibitorilor pompei de protoni induce condiții favorabile germinării sporilor de Clostridium difficile în tractul gastrointestinal.

Clostridium difficile biocolonizează multe animale domestice și sălbatice. Clostridium difficile este o bacterie complexă, capabilă să dezvolte forme de rezistență care parazitează tractul gastrointestinal al omului și nu numai. Sursa importantă în infecția cu Clostridium difficile o reprezintă, în primul rând, medicația cu antibiotice administrată în comunitate și fără aviz medical, precum și alimentația.

\section{Introduction}

Clostridium difficile is a microorganism - a Gram-positive anaerobic bacterium that has developed and hyperspecialized the ability to form spores. Outside the host, Clostridium difficile germinates spores which are resistant to unfavorable environment and for an extremely long time period ${ }^{(1)}$. The target anatomy of Clostridium difficile is the gastrointestinal tract. Clostridium difficile infection frequently occurs on a background of major disturbances in the balance of the normal intestinal flora caused by use for therapeutic purposes of broad-spectrum antibiotics ${ }^{(1)}$. The sequence of biological and biochemical events that precede the induction of the Clostridium difficile infection in the gastrointestinal tract is not known. Thus the Clostridium difficile infection occurs after a patient treated with broad-spectrum antibiotics ingests infectious resistant spores. In the gastrointestinal tract, Clostridium difficile spores pass from a latent state into metabolic activity, a process defined and known as the primary germination state ${ }^{(2,5)}$.

Clostridium difficile spores start the germination process in the duodenum. The germination of Clostridium difficile spores progresses in two stages, and it depends on: $\mathrm{pH}$ in the gastrointestinal tract, bile salt concentration, locally available calcium ions or other bivalent cations, and presence of certain free amino acids ${ }^{(2,3,4)}$. The germination process is remarkable and widely studied as it is the first and most important stage of the pathogenesis process. Recent experimental studies have attempted to decipher the molecular signals that lead to metabolic activation of the resistance forms of the pathogen. Initially it was thought that an increase in the gastrointestinal tract leads to a 
specific binding to certain enterocyte receptors, intracellular and extracellular ${ }^{(6,7,8)}$. Unfortunately, subsequent molecular studies did not identify any direct link between enterocyte membrane receptors and the occurrence of Clostridium difficile spores ${ }^{(6,7,8)}$. Of amino acids, only serine, glycine and alanine seem to play an important role in the activation of Clostridium difficile spores, but the germination mechanism induced by amino acids remains uncertain ${ }^{(5,9)}$. Another mechanism of the germination process of Clostridium difficile spores is represented by bivalent cations. Of bivalent cations, calcium and magnesium seem to be involved in the germination process of Clostridium difficile spores, but their mechanism of involvement in germination remains uncertain ${ }^{(10)}$. Once the germination process is completed, the colonization process and the specific pathogenicity of the microparasite are carried out. Clostridium difficile entering metabolic activity will progressively produce enterotoxin $A$ and cytotoxin B that cause diarrhea and pseudomembranous colitis in infected subjects $^{(11)}$. Once these toxins have been synthesized, they specifically bind to enterocyte membrane receptors leading to the destruction of the intestinal mucosa, diarrhea and acute colitis.

There are five different types of Clostridium difficile, each dominant on a particular continent: clade 1 (Europe), clade 2 (North America), clade 3 (Africa), clade 4 (Asia), and clade 5 (Australia) $^{(11)}$. Clostridium difficileinduced mortality is closely related to the type and synthesis of binary toxins. A percentage of over $50 \%$ of the subjects infected with Clostridium difficile were recently discharged from the hospital, outpatients or subjects with various immunosuppressive pathologies (inflammatory diseases, various cancers, AIDS, gastrointestinal pathologies, and metabolic diseases). Most communityacquired Clostridium difficile infections are also related to nosocomial infections (onset after hospital discharge or after a visit to a medical facility) or unwarranted use of broadspectrum antibiotics ${ }^{(12)}$. Patients infected with Clostridium difficile in medical facilities are usually elderly people, immunosuppressed or subjected to an antibiotic medication regimen (Gupta and Khanna, 2014). Compared to the above mentioned patients, community infections often occur in women aged under 50 years, and $20 \%$ of these patients have not received any antibiotic treatment during the 180 days prior to diagnosis (De Pestel and Aronoff, 2013). Some epidemiological studies have shown that antibiotic treatment increases approximately 7 times the risk of Clostridium difficile infection in certain patient categories $^{(13)}$. The most common antibiotics previously used by patients with a diagnosis of Clostridium difficile infection were: clindamycin, fluoroquinolones, cephalosporins, penicillins, macrolides, and sulfonamides ${ }^{(14)}$. Not only antibiotics are a risk factor in Clostridium difficile infections, but proton-pump inhibitors and $\mathrm{H} 2$ antagonists may also represent a risk factor in microparasitic infections ${ }^{(15)}$. Wide-scale community use of antibiotics and protonpump inhibitors creates favorable conditions for the germination of Clostridium difficile spores in the gastrointestinal tract.

\section{Material and methods}

The data were taken from the Department of Public Health of Constanta, and the reporting and processing of medical information was for the time period between February 8, 2015 June 4,2016 . Only the medical information of patients aged over 18 years who live in a rural settings was included in the study. The study 


\section{INTER}

\section{rural setting}

18 patients

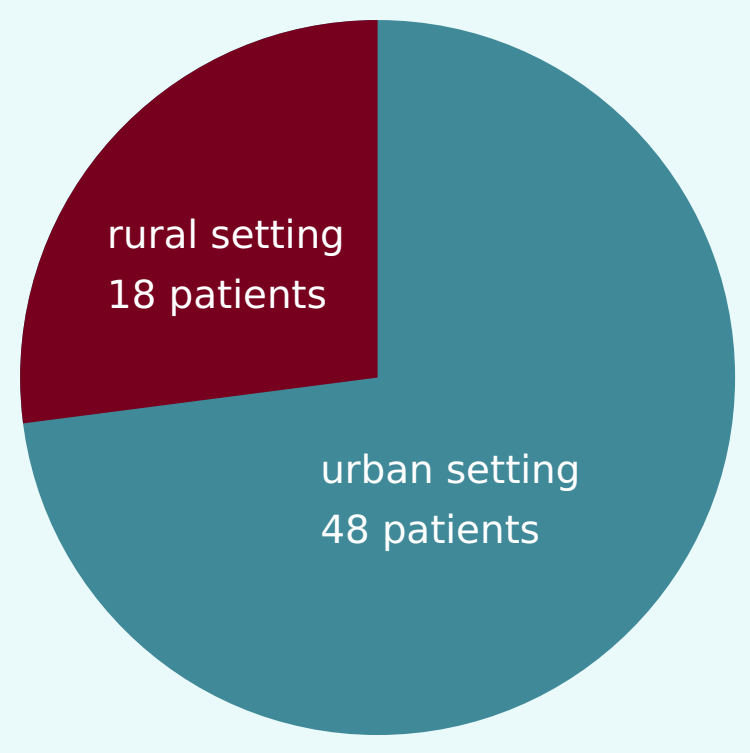

Figure 1. Comparison of Clostridium difficile infections by urban and rural settings

\begin{tabular}{|c|c|c|c|c|c|c|c|c|c|}
\hline \multirow{3}{*}{$\begin{array}{c}\text { Male } \\
\text { patients }\end{array}$} & \multirow{2}{*}{$\begin{array}{c}\begin{array}{c}\text { Patient } \\
\text { age }\end{array} \\
\begin{array}{c}18-30 \\
\text { years old }\end{array}\end{array}$} & \multicolumn{2}{|c|}{$\begin{array}{c}\text { Medical } \\
\text { history of } \\
\text { Clostridium } \\
\text { difficile }\end{array}$} & \multirow{2}{*}{$\begin{array}{c}\begin{array}{c}\text { Patient } \\
\text { age }\end{array} \\
\begin{array}{c}30-50 \\
\text { years old }\end{array}\end{array}$} & \multicolumn{2}{|c|}{$\begin{array}{c}\text { Medical } \\
\text { history of } \\
\text { Clostridium } \\
\text { difficile }\end{array}$} & \multirow{2}{*}{$\begin{array}{c}\begin{array}{c}\text { Patient } \\
\text { age }\end{array} \\
>50 \text { years } \\
\text { old }\end{array}$} & \multicolumn{2}{|c|}{$\begin{array}{c}\text { Medical } \\
\text { history of } \\
\text { Clostridium } \\
\text { difficile }\end{array}$} \\
\hline & & Yes & No & & Yes & No & & Yes & No \\
\hline & $n=3$ & $n=2$ & $n=1$ & $n=1$ & $n=0$ & $n=1$ & $n=8$ & $\mathrm{n}=1$ & $n=7$ \\
\hline $\begin{array}{l}\text { Female } \\
\text { patients }\end{array}$ & $n=0$ & $n=0$ & $n=0$ & $n=1$ & $\mathrm{n}=1$ & $\mathrm{n}=0$ & $n=5$ & $n=5$ & $n=0$ \\
\hline
\end{tabular}

Table 2. Reporting of patients in a rural setting by incidence and medical history 
protocol was signed and approved by the Institutional Review Board and the Ethics Committee of the Department of Public Health of Constanta. The data was processed in compliance with the legal requirements on the use of personal data. During hospitalization, patients were actively followed to collect data on the evolution of diarrheal episodes, the onset of medical complications, and death. The diagnosis of Clostridium difficile infection was confirmed by the determination of toxin $A$ and $B$ and glutamate dehydrogenase via chemiluminescence in faeces.

Of the total number of patients $(\mathbf{n}=\mathbf{6 6})$ with a positive result for Clostridium difficile infection in the study period, only 18 patients $(\mathbf{n}=\mathbf{1 8})$ were from a rural setting.

\section{Results}

The table shows the medical history of patients in a rural setting, the incidence by age and gender of Clostridium difficile infection, and the source of the infection (communityacquired or nosocomial) can be grossly deduced.

\section{Discussions}

Both symptomatic patients and asymptomatic carriers eliminate Clostridium difficile spores in extremely high amounts. Recent studies have shown that newborns are the source of infection in over $60 \%$ of cases rather than a maternal source. Pseudomembranous colitis may occur infrequently in infants, and could be explained by the cumulative expression of toxin receptors via the two pathways mentioned in the introduction, which are poorly developed. Regarding the information available in literature, women are two times more prone to Clostridium difficile infection than men. Infants may be an important source of active or inactive forms of Clostridium difficile microparasite, which may largely explain the incidence of Clostridium difficile infection in peripartum women. The major source of the Clostridium difficile infection is mainly the antibiotic medication performed in the community without consulting a healthcare professional, but also food. The proven resistance of Clostridium difficile spores in thermally processed meat demonstrates the survival ability of resistance forms of the microparasite in extreme environments. Thus, thermal processing of food can be a possible source of infection with Clostridium difficile. Farm animals are a good vehicle for the resistance forms of the Clostridium difficile bacterium. Therefore, the emergence of extra-hospital infections with Clostridium difficile may be related to zoonotic transmission. Clostridium difficile biocolonizes many domestic and wild animals, for example, actual carriers of biological forms of the Clostridium difficile bacterium can be: dogs, cats, horses, pigs, calves, poultry, goats, and rodents. Another aspect not to be neglected in the transmission and transport of multidrugresistant forms of pathogenic microorganisms is the use of antibiotics in the zootechnical field. There is sufficient experimental and epidemiological evidence in this respect, but also a series of measures imposed on EU member states. These studies show that the use of antibiotics can indirectly influence spore germination, and hence the susceptibility of rural communities to contact and develop infections with Clostridium difficile. Literature analysis and data are a first step in identifying possible transport sources and environmental factors that contribute to the development of Clostridium difficile bacteria. The data presented is informative for the medical community and especially important for health education programs. 
Clostridium difficile is a complex bacterium capable of developing resistant forms that parasitize the gastrointestinal tract of humans, and other animals.

\section{Conclusions}

Clostridium difficile is a complex bacterium capable of developing resistant forms that parasitize the gastrointestinal tract of humans, and also many animals. An important source of the Clostridium difficile infection is represented primarily by antibiotic medication administered in communities without medical recommendation, as well as food.

\section{References}

1. Kochan TJ, Shoshiev MS, Hastie Jessica L, Somers Madeline J, et al. Germinant Synergy Facilitates Clostridium difficile Spore Germination under Physiological Conditions. Host-Microbe Biology, msphere.asm.org, September/October 2018; Volume 3, Issue 5 e00335-18.

2. Setlow P, Wang S, Li YQ. Germination of spores of the orders Bacillales and Clostridiales. Annual Review of Microbiology, 2017; 71:459-477.

3. Moir A. How do spores germinate? Journal of Applied Microbiology, 2006; 101:526-530.

4. Poutanen SM, Simor AE. Clostridium difficileassociated diarrhea in adults. Canadian Medical Association Journal, 2004, 171:51-58.

5. Kochan TJ, Foley MH, Shoshiev MS, Somers MJ, Carlson $P E$, Jr, Hanna PC. Updates to Clostridium difficile spore germination. Journal Bacteriology, 2018; 200:e00218-18.

6. Francis MB, Allen CA, Shrestha R, Sorg JA. Bile acid recognition by the Clostridium difficile germinant receptor, CspC, is important for establishing infection. PLoS Pathog 9, 2013; e1003356.

7. Francis MB, Allen CA, Sorg JA. Spore cortex hydrolysis precedes dipicolinic acid release during Clostridium difficile spore germination. Journal Bacteriology, 2015; 197:2276-2283.

8. Francis $M B$, Sorg JA. Dipicolinic acid release by germinating Clostridium difficile spores occurs through a mechanosensing mechanism. mSphere 1, 2016; e0030616.

9. Shrestha R, Lockless SW, Sorg JA. A Clostridium difficile alanine racemase affects spore germination and accommodates serine as a substrate. Journal Biological Chemistry, 2017; 292:10735-10742.

10. Kochan TJ, Somers MJ, Kaiser AM, Shoshiev MS, Hagan $A K$. et. al. Intestinal calcium and bile salts facilitate germination of Clostridium difficile spores. PLoS Pathog, 2017; 13:e1006443.

11. Brown A. W.W, Wilson R.B. Clostridium difficile colitis and zoonotic origins - a narrative review. Gastroenterology Report, 2018,6 (3), 157-166.

12. Gupta A, Khanna S. Community-acquired Clostridium difficile infection: an increasing public health threat. Infection and Drug Resistance, 2014;7:63-72.

13. De Pestel DD, Aronoff DM. Epidemiology of Clostridium difficile infection. Journal Pharmacy Practice, 2013; 26:464-75.

14. Deshpande A, Pasupuleti V, Thota P et al. Communityassociated Clostridium difficile infection and antibiotics: a metaanalysis. Journal of Antimicrobial Chemotherapy, 2013; 68:1951-61.

15. MezoffEA, Cohen MB. Acid suppression and the risk of Clostridium difficile infection. Journal of Pediatrics, 2013; 163:627-30. 